\title{
Security Agents, Security Threats and the Culture of Impunity: Antithesis to Nigeria's Socio-Economic Development and Political Stability
}

\author{
Edoka Unaji \\ Department Of Social Studies, \\ College Of Education, Oju, Benue State, Nigeria
}

\section{Doi:10.5901/jesr.2013.v3n6p147}

\begin{abstract}
The issue of security has taken the front burner in Nigeria in particular and the world at large in recent time. However, security situation in Nigeria did not deteriorate just within a day but has been on a sliding drift for sometime as a result of failure on the part of authorities to attend to security threats or put in place counter measures to contain risk events. Situations that exemplify security threats in Nigeria includes the political thugs that are being equipped with arms and ammunitions, the police force that extort money from the polity with impunity, elections that are blatantly manipulated and rigged, the degradation of the environment, extreme poverty, political marginalization and exclusion, general corruption, etc. This paper has therefore explored the impact of insecurity and impunity on Nigeria's socio-economic and political development and has also suggested measures such as good understanding of the concept of security, security threat, capacity building, reduction in poverty rate, political inclusion, etc. as way out of our present security quagmire.
\end{abstract}

Keywords: Security, threats, insecurity, impunity and pervasive.

\section{Introduction}

Security seen from the very elementary or simplest perspective is all about the safety and protection of lives and properties. In contemporary time however, security is viewed within a broader spectrum of which, in the opinion of Eselebor (2008), includes issues such as food, poverty, disease, weather, bad governance, crisis and conflicts, etc. In other words, one cannot be said to be enjoying any reasonable measure of security when there is either pervasive hunger and poverty or wide spread crisis and conflict all over the country. It is on this premise that Eselebor has therefore viewed security as the "condition of being protected against danger or loss".

\section{Conceptual Clarification}

Security agents refer to those instruments especially humans, structures and processes that are charged with the responsibility of ensuring the protection and safety of lives and properties from danger or harm. In modern societies, security agents include the police, the armed forces, other para-military organizations such as the customs, immigration service, civil defence corps, trained animals and other mechanized structures.

Security threats on the other hand refers to a situation whereby there is the real and reasonable degree of a risk factor or risk event being triggered off. In other words, security threats can be said to exist when there is a likelihood of a risk event occurring if no counter measure or preventive measure is taken as fast as possible. Situations that exemplify security threats in Nigeria and other developing countries of Africa includes political thugs that are being equipped with arms 
and ammunitions who most often become willing tools as hired assassins or armed robbers, the police authorities that extorts money from people in general and suspects in particular, the blatant manipulations and rigging of elections, the degradation of the environment especially in the Niger Delta, religious intolerance, extreme poverty and hunger, etc.

The culture of impunity as used in this context presupposes a situation whereby people do things that are known to be immoral and wrong, yet not subjected to any punitive measure by relevant authorities.

\section{Government and the Culture of Impunity in Nigeria}

Government which is the machinery for the coordination and administration of the polity and resources of the state exist mainly at three levels in Nigeria. At all levels of governance, budgeting has become an annual ritual that is just presented to, and passed by the legislature only to be abandoned immediately after. Although non-implementation of budget is an offence punishable as prescribed by schedule 143 of the 1999 constitution of the Federal Republic of Nigeria, no president or governor has ever been removed or even sanctioned in Nigeria for failure to implement budget.

In the same manner officials found guilty of corruption such as former governor DSP Alamieshghea has been granted dubious state pardon (Daily Sun. wed. May $29^{\text {th }} 2013$ ) and Harold Demuren of Aviation Authority found guilty of incompetence and dereliction of duty and recommended for sack by the National Assembly (The Nation, Tuesday April 9, 2013) has been left by the Government to continue in office with impunity.

Though, President Jonathan made a stunning revelation that the Boko Haram sect had infiltrated his government (The Nation, January, $9^{\text {th }}$ 2013) yet, he did nothing proactively to neutralize the situation. Government's weakness and inability to resolve basic issues of hunger, unemployment, shelter, HIV/AIDS, poverty, political exclusion among many others has led to the volatile security situation in Nigeria which has negatively affected socio-economic development and political stability. The military in Nigeria frog jump citizens on flimsy excuses or violate their rights with impunity. The Daily Sun Newspaper of J uly $10^{\text {th }}, 2013$ (page 34) gave a horrid account of how one Group Captain Garba of Nigerian Air force, Abuja allegedly ordered the arrest and torture of three artisans with hot pressing iron and boiling rings. Governor Fashola of Lagos state according to the Nation Newspaper of $25^{\text {th }}$ July, 2012 had to personally arrest an army colonel and a sergeant for violating the Bus Rapid Transit (BRT) traffic rules in Lagos.

Elsewhere in Africa Yoweri Museveni who came to power in Uganda via military coup has since transformed into a civilian president, having declared himself winner in about five presidential elections. Robert Mugabe who was elected president of Zimbabwe at independence in 1980 has continued to manipulate the country's constitution and the electoral processes. Similarly, Omar EI Bashir of Sudan has not only ruled his country with absurdity and impunity but has equally ignored the International Court of J ustice (ICJ) charges of crime against humanity with utmost impunity.

The implication of all these is that political leadership and governance in Africa has become a mirage and left the people without direction. This has left Africa crises-ridden and therefore made socio-economic development, peace and political stability a near impossibility.

\section{Insecurity and the Culture of Impunity as They Affect Socio-Economic Development and Political Stability in Nigeria}

The progressive deterioration in the quality of living and the lives of Nigerians generally can only be adequately explained within the context of the prevalent absurdities such as massive corruption, pervasive poverty and hunger, unemployment political marginalization and exclution, epileptic power and energy crises, failure of agriculture, ravaging HIV/AIDS pandemic, degradation of the environment among many others. Corruption in high and low places in Nigeria dates far back in history. The leader of the very first military coup in Nigeria, Major Nzeogwu attributed their coup to 
corruption as he had declared in Ademoyega (1981) that:

Our enemies are the political profiteers, the swindlers, the men in high and low places that seek bribe and demand 10\%. Those that seek to keep the country divided so that they can remain in office as ministers or VIPS at least, the tribalist, and the nepotist, those that make the country look big for nothing before international circle, those that has corrupted our society and put Nigerian Political calendar back by their words and deeds.

In the same vein General Obasanjo in Ayua (2001) had also stated that "corruption has been responsible for the instability of successive governments since the first republic". Thus, the successive years of massive corruption in Nigeria has not only left the economy in shamble but the generality of the people highly impoverished, hopeless and agitated.

Industrial complexes such as the National Fertilizer Company of Nigeria, (NAFCON), Ajaokuta Steel Complex, Nigeria Telecommunications Limited (NITEL), etc have all been wrecked as a result of massive corruption and general kleptomania. This has led to thousands of people losing their employment and means of lively hood.

The effect of this on socio-economic development in Nigeria includes abysmal failure to achieve the national developmental objectives, wide spread poverty, collapsed socio-economic infrastructure, high rate of unemployment which has led to youth restiveness, emergence of militia groups, capital flight and low direct foreign investment. All these in concert distort and retard socioeconomic development and political stability in Nigeria. The wide spread insecurity in Nigeria coupled with the culture of impunity on the part of authorities has also impeded and ultimately hindered national integration as most Nigerian no longer feel safe outside their ethnic enclave.

This has negatively affected not only our national integration efforts but general socioeconomic development and political stability.

\section{Political Marginalization and Exclusion}

The crises of confidence and suspicion arising from perceived and established cases of political marginalization and exclusion came to a turning point in Nigeria with the annulment of the June, 1993 presidential election generally believed to have been won by chief MKO Abiola, a Yoruba ethnic national from the south western Nigeria. The Yoruba nation in particular and many other Nigerians in general perceived the annulment as the Hausa/Fulani conspiracy to deny other ethnic nationals active participation in the rulership and governance of Nigeria. Thus Nigeria was plunged into unprecedented political crises which invariably hampered socio-economic development in the country.

The same scenario can be said to be gradually emerging in Nigeria as Asari Dokubo and Kingsely Kuku among others have made inflammatory statements to the extent that Nigeria will go to blazes should Jonathan fail in his 2015 Presidential bid (Daily Sun, Mon. May 6, 2013).

The cumulative effect arising from the scenario above is atmosphere of mutual suspicion between the component ethnic nationalities in Nigeria which has not only negatively affected national integration efforts, political stability, socio-economic development but also peaceful coexistence.

\section{Negative Impact of the Culture of Impunity in Nigeria}

In Nigeria budgets are passed only as rituals as neither governors nor the president cares much about its implementation. Although non-implementation of budget is an offence punishable as prescribed by schedule 143 of the 1999 constitution of the Federal Republic of Nigeria, no governor or president has ever been so removed from office or sanctioned for non implementation of budget. Moreover, the prevalent reign of terror in Nigeria has led to wide spread and heightened 
fear as Government and relevant authorities have largely failed to take necessary measures either to counter the security threats or contain risk events. This has negatively affected socio-economic development as Nigeria losses over 7 billion naira daily to oil thieves according to Governor Uduaghan who heads the oil theft committee of the National Economic Council (The Nation, Friday July, $19^{\text {th }} 2013$ front cover page).

\section{The Need for Paradigm Shift in Tackling the Pervasive Security Problematique in Nigeria and the Larger Africa}

Lamenting the inadequacy of Nigeria's effort to confront the ubiquitous security challenges facing the nation, Orngu (2010 p36) had contended that:

the countries feeble attempts at addressing these challenges have always been short-term reactive responses to internal crises with emphasis on the deployment of coercive or militaristic apparatuses of the state without adequate attention to proactively addressing the very causes of the crises such as poverty, socio-economic hardship, political exclusion and marginalization.

In the same vein, McNamara in Eselebor (2008) is of the opinion that societies that seek to achieve adequate military security against the background of acute food shortages, population explosion, low level of productivity, inefficient public utilities, problems of unemployment, etc. has a false sense of security.

From the foregoing therefore, to effectively address the challenges of wide spread insecurity in Nigeria will demand the resolution of the underlying issues of wide spread poverty, the ravaging HIV/AIDS pandemic, Environmental degradation, epileptic energy and power supply, unemployment, decaying infrastructure in health and educational sector, political exclusion and marginalization among many others

\section{The Way Forward}

Most countries in the developing world including Nigeria have the false impression about security. Most often, they equate security with military weapons, military and para-military personnels, money and the likes while relegating factors such as food, population, education, employment, energy crises, poverty, diseases etc to the background. Specifically therefore, as government and as a people we must endeavour to do the followings in order to stem the tide of pervasive insecurity in the continent.

Understanding of Security in proper perspective: The ruling elites, especially those occupying governmental position and other public offices must re-define security in proper and broader perspective as against the traditional and conservative confines of arms and associated paraphernalia.

Timely handling of threats: It was said that warning messages of impending attacks by the Boko Haram sect on Abuja and Kano were received prior to the deadly attacks on the United Nations Office in Abuja, police formations in Kano and even the gruesome massacre of students and teachers of a Government boarding school in Yobe State on the 7th of July, 2013 (Weekly Trust Newspaper of 13th July, 2013 pg. 4). Government must be prepared to embark on counter security measures when there is information about threat to peace.

Reducing the level of vulnerability: This is all about the drastic reduction in the level or degree of certainty that certain risk events are to occur. In this wise Government must make efforts to provide gainful employment for the teeming youths who most often become willing tools in the hands of dubious politicians and potentates as hired assassins, armed robbers, cultist, etc.

Capacity Building and Strengthening of Institutional Frame work 
Special Courts need to be established and proactive legislation enacted to handle cases of kidnapping and terrorist activities, while anti-graft agencies such as Economic and financial Crimes Commission (EFCC) and Independent and Corrupt Practices Commission need to be strengthened.

Living by example: leaders holding political and public offices should embrace the culture of transparency and accountability both in their official and private life.

Doing Away with the Culture of Impunity: The culture of Impunity has developed because of the complacency and docility of the people. We must as a people refuse association with people of dubious and questionable means.

The military high command though not in themselves insulated from the problems must be able to re-orientate their officers and men to the fact that their primary duty is to protect the people of Nigeria, and therefore should not see them as enemies to be defeated or captured.

Amendment of the relevant sections of the constitution: this should be with the view to removing paradoxical concepts such as Federal character, quota system, state indigene and other such provisions in the constitution that have continued to be a draw back to our national integration efforts.

\section{Conclusion}

From all the point of views expressed in this paper, it is our contention that redefining the concept of security, re-orienting ourselves in terms of value system, resolution of underlying issues such as poverty, energy crises, political marginalization, unemployment among others and; our collective determination to move Nigeria to the next level will definitely see us through the current security challenges.

\section{References}

Ademoyega .A. (1981) Why we struck. The story of the first Nigerian Coup. Ibadan. Evans Brothers Nigeria Publishers Ltd.

Ayua, I.A. (2001) Overview of Corruption in Nigeria. Nigeria Journal of Political and Administrative Studies. Vol. 1 No. 2. Department of Political Science, Benue State University, Makurdi.

Collier, Elliot, Hegree, Hoeffler, Reynal-Querol and Samabanis (2003). Breaking the conflict trap-civil war and development studies policy. Washington D.C. The World Bank.

Eselebor, A.W (2008) The security challenges of forced immigration in Nigeria. The Nigerian Army Quarterly Journal. Vol. 4 (page 230-248).

Isiguzo, J. (2012) Colonel Arrested by Fashola to pay N25,000 fine says Army. The Nation 25th July, 2012. (Pg8). Lagos. Vintage Press Limited.

Orngu, C.S (2010) Reconstruction of Nigeria's national Security Discuss for Nation Building. Makurdi. Book makers Publishing.

Daily Sun Wed. May $29^{\text {th }}, 2013$, Insight: Alameishghea tries to amend history (Page 57). Lagos. The Sun Publishing Company.

Daily Sun Mon. May 6 ${ }^{\text {th }}, 2013$ (Page 5) 2015: Nigeria will Burn if J onathan fails-Asari Dokubo. Lagos. The Sun Publishing Company.

Daily Sun Wed. July $10^{\text {th }}, 2013$, Human Angle: How Airforce Officer tortured us with Hot Iron. Lagos. The Sun publishing Company

The Nation Mon. January $9^{\text {th }}, 2012$; President: Boko Haram Has infiltrated Government, military (Front Cover Page, p4) Lagos. Vintage Press Limited

The Nation: Tuesday. April, 9th 2013. (Front Cover Page) Tambuwal Cautions government against exconvicts pardon. Lagos. Vintage Press Limited

The Nation: Friday. July, 19th 2013. (Front cover Page) Thieves steal 7.3 billion naira oil daily Lagos. Vintage Press Limited.

The Nation Thursday. December 20 ${ }^{\text {th }}, 2012$ (Front Page \& P4.) How Dana Air crash probe indicts NCAA, Airline. Lagos. Vintage Press Limited. 
The 1999 Constitution of the Federal Republic of Nigeria and Fundamental Rights (Enforcements Procedures) Rules 2009.

Weekly Trust: Sat. July 2013; Untold Story of Yobe School Massacre. Abuja. Media Trust Nigeria Ltd. 